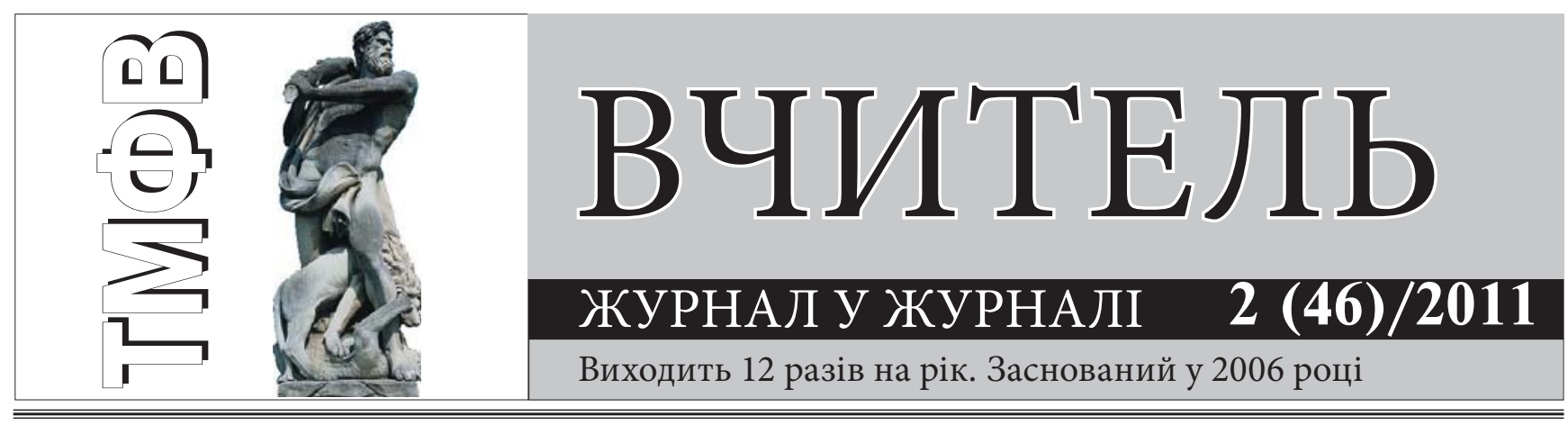

\title{
ЗАКОНОМІРНОСТІ РОЗВИТКУ СИЛОВИХ ЗДІБНОСТЕЙ У ФІЗИЧНОМУ ВИХОВАННІ І СПОРТІ. ПОВІДОМЛЕННЯ ІІ
}

\author{
Худолій О.М. \\ Харківський національний педагогічний університет імені Г.С. Сковороди
}

\begin{abstract}
Анотація. В статті узагальнені підходи до розвитку силових здібностей. Розглянуті підходи до реалізація принципів фізичного виховання в процесі розвитку сили; методика програмування розвитку сили. Ключові слова: силові здібності, принципи фізичного виховання, програмування.
\end{abstract}

Вступ. У статті на основі аналізу літератури виділені аспекти теорії і методики розвитку силових здібностей які вимагають узагальнення:

- реалізація принципів фізичного виховання в процесі розвитку сили;

- методика програмування розвитку сили.

Зв'язок роботи з науковими програмами. Робота виконана згідно плану наукових досліджень кафедри ТМФВ Харківського національного педагогічного університету імені Г.С. Сковороди.

Мета дослідження - узагальнити методологічні підходи до розвитку силових здібностей у фізичному вихованні.

Методи дослідження. Для досягнення мети дослідження були використані як філософські, так і загальнонаукові методи, серед яких:

- діалектичний метод;

- системний підхід;

- аналіз і узагальнення науково-методичної літератури.

Виклад основного матеріалу. Розвиток сили здійснюється на основі реалізації принципів фізичного виховання (приничи безперервності, приниип системного чергування навантаження $i$ відпочинку, приниип поступового збільшення тренувальних впливів, принцип изилічної будови системи занять, принцип вікової адекватності процесу бізичного виховання).

1. Приниип безперервності. Він орієнтує на формування довготривалої адаптації організму

() Худолій О.М., 2011. юних спортсменів до фізичних навантажень. Головною умовою формування стійкої адаптації $€$ безперервність і наступність ефектів попередніх занять. «Структурна ціна пристосовування» у спортсмена, який багато разів втрачав і відновлював свою тренованість, є набагато більш високою, ніж у спортсмена, який на ділі реалізував принцип безперервності спортивного тренування і зберіг стійке пристосовування. Дане положення істотне, оскільки здатність генетичного апарату клітини і апарату синтезу білка генерувати макромолекули не безмежна. Багатократна активація біосинтезу, необхідна для багатократного відновлення втраченого системного структурного сліду, може привести до своєрідного локального зношування органів, що входять в систему, відповідальну за пристосовування (Ф.3. Меерсон).

Таким чином, принцип безперервності стає принципом економного витрачання структурних ресурсів організму в процесі розвитку сили, принципом дуже важливим для попередження явищ зношування і забезпечення довговічності в спорті. Принцип логічно поєднується з приниипом системного чергування навантаження $і$ відпочинку.

2. Приниип системного чергування навантаженняівідпочинку. Положенняпринципусформульовані переважно на основі закономірностей етапності і фазності розвитку рухових здібностей і вимагає дотримання повторюваності і поступовості педагогічних дій.

Під повторюваністю розуміється багатократне виконання навантаження як в рамках одного окре- 
мо взятого заняття, так і системи занять, з'єднаних у тижневі, місячні, річні цикли.

Повторюваність дій припускає чергування роботи і відпочинку, а отже, пред'явлення навантажень в різних фазах працездатності. Останнє створює акцентованість дій, коли одне і те саме за об'ємом і інтенсивністю навантаження, яке пред'являється в різних фазах, може викликати різну функціональну активність органів і структур. Як в одному занятті, так і в системі занять навантаження можуть пред'являтися або у фазі підвищеної працездатності організму, або у фазі тимчасового їі зниження. У тому або іншому випадку відбувається сумація слідів попередніх дій, але в першому досягається поступальне, а в другому - відставлене підвищення працездатності. В останньому випадку підвищення працездатності спостерігається не від навантаження до навантаження або від заняття до заняття, а через певний цикл навантажень або занять. Значення такої сумації - пред’явити організму об'ємні навантаження, викликати тим самим істотні адаптивні перебудови і отримати у результаті значний приріст у розвитку рухових здібностей (Ю.В. Верхошанський, 1988).

3. Приниип поступового збільшення тренувальних впливів. Згідно закономірності поетапного розвитку здібностей, необхідне дотримання поступовості наростання величини навантаження, як в окремому занятті, так і в системі занять. Динаміка підвищення навантаження повинна відповідати динаміці анатомо-морфологічних і психофізіологічних змін, що припускає посилення дій у міру пристосування органів і структур до навантажень, що пред'являються. Величина навантаження складається з об'єму механічної роботи, виконуваної з різною інтенсивністю. Як наслідок цього, підвищення навантаження визначатиметься або за рахунок збільшення об’єму роботи, або за рахунок інтенсивності ії виконання (кількості роботи в одиницю часу), або одночасної зміни першого і другого компонентів. Поступовість динаміки навантажень знаходиться в певному співвідношенні з темпом пристосувальних змін, які проходять в організмі.

Пристосування до того або іншого навантаження не може відбуватися відразу, одночасно. Для того, щоб відбулися стійкі зрушення в системах організму, що дозволяють піднятися на новий рівень навантажень, необхідний час. У практиці фізичного виховання вважається, що стійкі зміни можуть відбутися упродовж одного місяця. Цей час залежить, з одного боку, від величини і якісних особливостей навантажень, а 3 іншого - від індивідуальних адаптаційних можливостей, які змінюються з віком і під впливом низки зовнішніх i внутрішніх (по відношенню до організму) чинників. 3 урахуванням даної залежності вико- ристовують різні форми поступового підвищення навантажень: прямолінійно-висхідну, східчасту, хвилеподібну.

У системі тренувальних занять для розвитку силових здібностей використовуються тренувальні навантаження $з$ періодом відновлення більше 24 годин (2-3 заняття). Після виконання навантажень у фазі неповного відновлення завжди йдуть навантаження з періодом відновлення менше 24 годин.

Таким чином, хвилеподібні коливання навантажень служать як би основним фоном, на який накладаються інші форми їх динаміки у загальній тенденції до зростання.

4. Принцип изилічної будови системи занять. Закономірностями, що визначають дане теоретичне положення, $є$ :

- біоритмічні особливості розвитку і життєдіяльності організму людини;

- залежність кумулятивних процесів адаптації функціональних систем від певної циклічності спеціалізованих реакцій організму на фізичне навантаження;

- гетерохронність циклічності процесів активізації, втоми та відновлення різних функціональних систем організму людини.

Принцип реалізується через методичні положення до яких відноситься:

- у формуванні плану фізичної підготовки необхідно враховувати фазність розвитку рухових здібностей та їх вікову динаміку;

- планування розвитку рухових здібностей здійснювати на основі сенситивних періодів їх розвитку;

- враховувати взаємозв'язок і взаємообумовленість рухових здібностей в розвитку рухової функції людини.

Циклічність фізичної підготовки проявляється в систематичному повторенні відносно закінчених структурних одиниць навчально-тренувального процесу - окремих занять, мікроциклів, мезоциклів, макроциклів. Серії занять повинні забезпечувати оптимальне співвідношення навантаження і відпочинку для досягнення комулятивного ефекту у розвитку рухових здібностей (табл. 1).

5. Приниип вікової адекватності процеcy бізичного виховання. Положення принципу сформульовані у відповідності до закономірностей гетерохронного розвитку рухових здібностей, i припускає обов'язкове виділення їх сенситивних періодів в процесі фізичного виховання. Принцип вимагає дотримання спрямованості педагогічних дій на випереджаючі в своєму розвитку органи, структури і здійснення індивідуального підходу в розвитку рухових здібностей.

На основі сформульованих принципів пропонується як приклад графік проходження на- 
вчального матеріалу в річному циклі тренувального процесу юних гімнастів 7-8 років (табл. 1).

Графік побудований з врахуванням принципових настанов (О.Н. Худолей, 2005):

1. Настанова на використовування положення про те, що процес навчання і тренування юних гімнастів будується на основі об'єктивно протікаючих термінового i довготривалого етапів пристосовування організму. У зв'язку 3 цим одиницею планування навчально-тренувального процесу є місячний мезоцикл. У місячному мезоциклі планується виконання задач, пов'язаних із спеціальною працездатністю, розвитком силових можливостей і навчанням юних гімнастів.

2. Настанова на декомпозицію задач навчання і тренування. У рамках навчання розв'язуються задачі розвитку рухових здібностей, підвищення рівня спеціально-рухової і функціональної підготовленості юних гімнастів, для освоєння конкретних вправ. Практично це реалізується в послідовному розміщенні навчально-тренувальних завдань однієї спрямованості на певному часовому відрізку. Порядок рішення задач і підбору навчально-тренувальних завдань наступний:

1) розвиток рухових здібностей, підвищення рівня функціональної підготовленості юних гімнастів;

2) навчання початковим і кінцевим положенням вправ;

3) навчання діям без яких неможливо виконати вправу, що вивчається;

4) навчання умінням управляти рухами, навчання підвідним вправам;

5) навчання вправам в цілому;

6) підвищення рівня функціональної підготовленості юних гімнастів;

7) навчання вправам у сполученні.

3. Настанова на використовування тренувальних навантажень, спрямованих на формування i реалізацію кумулятивного тренувального ефекту. В мезоциклі використовуються блоки тренувальних навантажень, направлених на формування i реалізацію КТЕ. Перший блок навантажень направлений на формування і реалізацію адаптивних реакцій нервово-м'язової системи. Результатом дії першого блоку є збільшення сили, відповідальних груп м’язів, і спеціальної працездатності. Другий блок навантажень направлений на формування i реалізацію адаптивних реакцій серцево-судинної системи. Результатом дії другого блокує підвищення спеціальної працездатності і створення передумов для ефективної взаємодії з діями першого блоку подальшого мезоциклу.

4.Настанова на використовування варіативності тренувальних навантажень по величині в трену- вальному занятті орієнтує на раціональний спосіб впорядкування об'єму тренувального навантаження. Використовування варіативності тренувальних навантажень в заняттях формує адекватну реакцію організму і сприяє відновленню функціонального стану організму в процесі тренування.

5. Настанова на використовування тренувальних навантажень, що забезпечують високий рівень працездатності на певномучасовому відрізку, орієнтує на раціональний спосіб впорядкування об'єму тренувальних навантажень в мікроциклі. Використовується варіативність тренувальних навантажень в мікроциклі. Понеділок, вівторок, субота - середнє навантаження; середа, п’ятниця - велике навантаження; четвер - мале навантаження. Практично настанова реалізується в період після застосування першого блоку навантажень і забезпечує високий рівень працездатності, необхідний для ефективного навчання рухам.

Відповідно до графіку кожного місяця $1-7$ заняття виділяється на розвиток координації рухів, 1-10 заняття на розвиток сили, 1-6 заняття на повторення вивчених вправ, 7-20 заняття на оволодіння новими вправами (табл. 1).

Послідовність, порядок розвитку сили визначається, по-перше, біологічними закономірностями розвитку організму i, по-друге, метою підготовки. Аналіз стану підготовленості, перспективи розвитку тренованості і визначення достатності їх для досягнення мети підготовки це основа технології розвитку рухових здібностей учнів.

Зростання сили пов'язано, 3 одного боку, 3 фізіологічним поперечником м'язу, морфофункціональними перебудовами на рівні ЦНС, а 3 іншого - 3 мобілізацією більшого числа мотонейронів і вдосконаленням міжм'язової координації.

Якщо для виконання силової вправи достатньо сили $\mathrm{X}+\mathrm{s}$, де $\mathrm{X}$ - середнє арифметичне, s стандартне відхилення, що характеризує коливання сили на 2-3 заняттях, то підвищення силових здібностей може проходити за рахунок вдосконалення міжм'язової координації, інакше - необхідні структурні перетворення на рівні м'язової і центрально-нервової систем. У першому випадку це досягається точним підбором рухових завдань, відповідних змагальній вправі. У другому випадку - оптимальним дозуванням силових навантажень на тривалому етапі підготовки.

Наприклад:

Для утримання «упору руки в сторони» на кільцях сила повинна бути рівна $87 \%$ від ваги тіла (дані Ю. В. Менхіна, 1988). Якщо спортсмен важить 60 кг, то сила груп м'язів, що приводять, повинна бути рівна 52,2 кг. Якщо спортсмен показує 


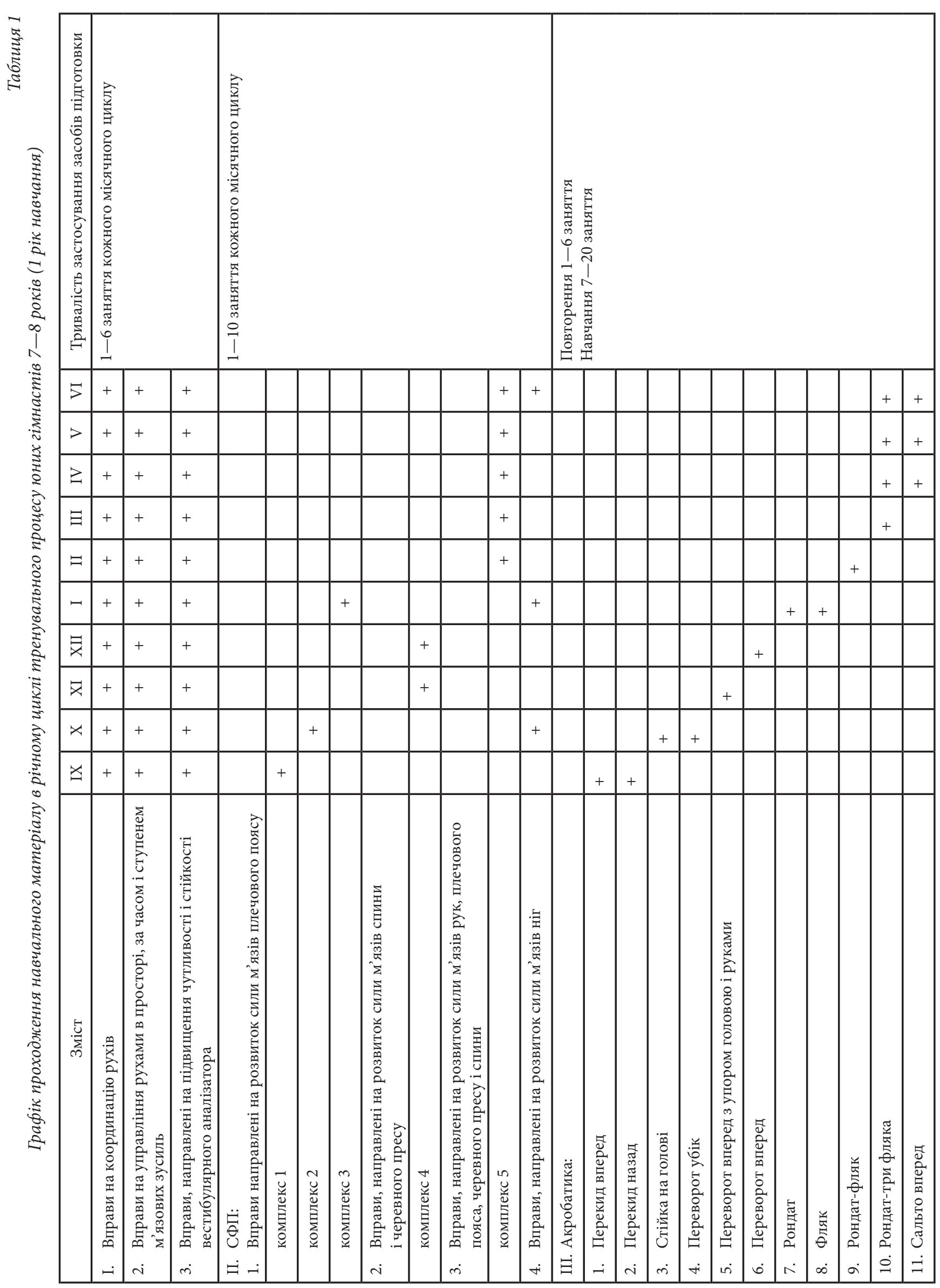




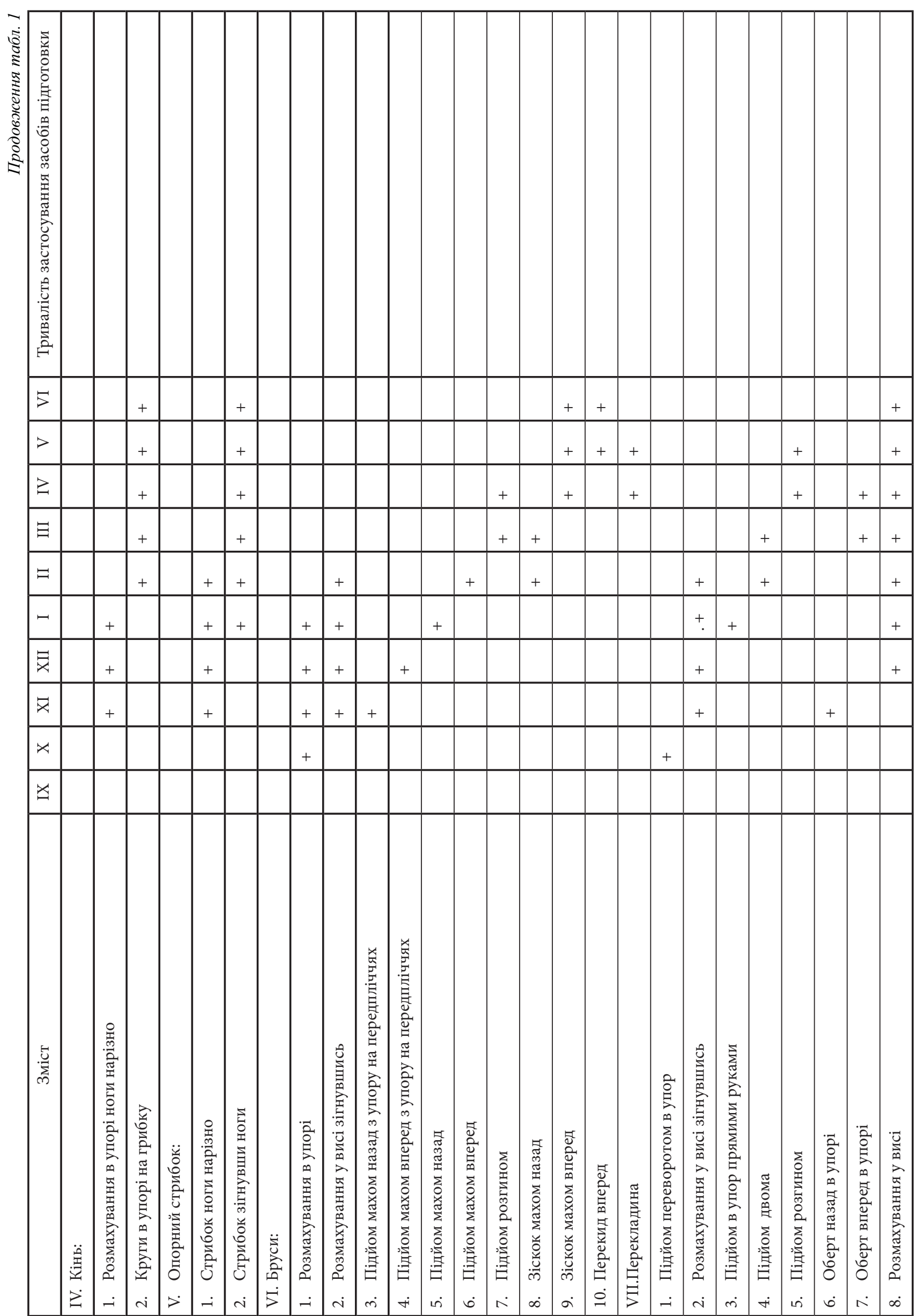




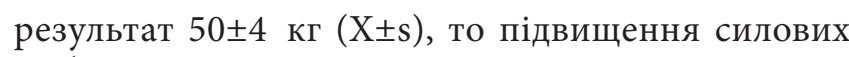
здібностей досягається за рахунок вдосконалення міжм'язової координації.

Розглянемо другий випадок розвитку силових здібностей. Для створення передумов для морфофункціональних перебудов необхідні фізичні навантаження. Якщо фізичне навантаження викликає виснаження енергетичних ресурсів організму (порушення гомеостазу), то відбувається надлишкове відновлення і переведення організму на новий, більш високий рівень функціонування (Ю.В. Верхошанський, 1988; В.М. Платонов, М.М. Булатова, 1995; В.А. Романенко, 2005).

Під впливом фізичних навантажень у клітинах багатьох фізіологічних систем виникає одне і те саме зрушення - дефіцит багатих енергією фосфорних сполучень та збільшення потенціалу фосфорування. У свою чергу це викликає активізацію генетичного апарату клітин, посилюючи синтез нуклеїнових кислот і білків. У результаті збільшується потужність системи мітохондрій, зростає вироблення аденозінтрифосфорної кислоти (АТФ) на одиницю маси тканини і дефіцит АТФ усувається (Ф.З. Меерсон, М.Г. Пшенникова, 1988; Ю.В. Верхошанський, 1985).

Фізичні навантаження в такому випадку повинні застосовуватися так довго, як це дозволяє період поновлення білка в м'язах спортсмена. За даними Ю. В. Верхошанського (1988) строк півперіода життя білків м'язів, тобто час, за який вони наполовину оновлюють склад, - біля 30 діб. А. В. Волков (1970) стверджує, що періодичні зміни величини максимальної мускульної сили гімнастів залежать від характеру і рівня обмінних процесів, тривалість таких процесів вкладається в період рівний 13,2 $\pm 1,7$ дня.
Можна припустити, що за певних умов, на протязі місяця занять фізичною культурою, можливі морфо-функціональні зміни позитивного спрямування в м'язовій і центрально-нервовій системах. Розглянемо ці умови.

У розвитку сили локальної групи м’язів слід оптимізувати навантаження і враховувати: 1) стан ЦНС; 2) скорочувальні здібності м'язів; 3) рівень енергетичного потенціалу спортсменів.

Оптимізація навантажень включає: 1) визначення величини на яку може зрости сила групи м'язів; 2) визначення впливу що неминуче приведе до зросту сили; 3) визначення тривалості такого впливу.

Для оптимізації силових навантажень використовується план факторних експериментів й алгоритм аналізу запропонований у попередніх роботах (О.Н. Худолей, 2005). Для визначення величини на яку може зрости сила групи м'язів аналізується розподіл приростів сили за результатами обчислювального експерименту (рис. 1). Для визначення режиму виконання силових вправ який приведе до оптимального зростання сили аналізується трьохвимірний розподіл приростів сили розгиначів передпліччя у юних гімнастів за результатами обчислювального експерименту (рис. 2).

Центральна нервова система зберігає високий функціональний стан за умови, якщо силова робота виконується в першій половині заняття. Скорочувальніздібності м’язів підвищуються, якщо ЦНС не знаходиться в стадії втоми, підібраний оптимальний вплив і поперечник м'язу має тенденцію до збільшення.

Аналіз наведеного вище матеріалу дозволив припустити, що енергетичний потенціал має тенденцію до збільшення, якщо:

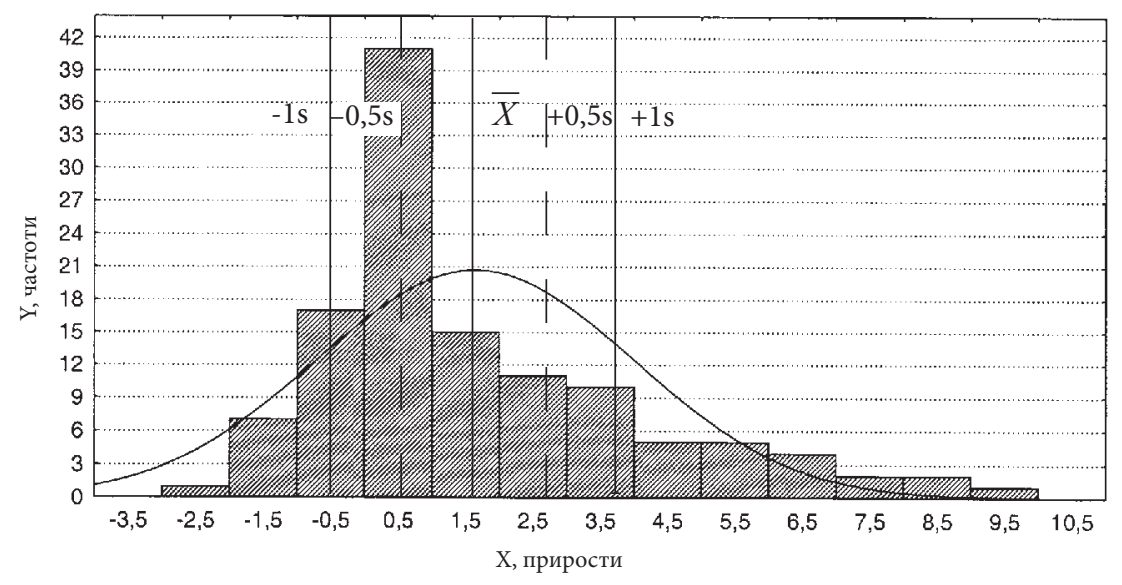

Рис. 1. Розподіл приростів сили розгиначів передпліччя у юних гімнастів за результатами обчислювального експерименту 


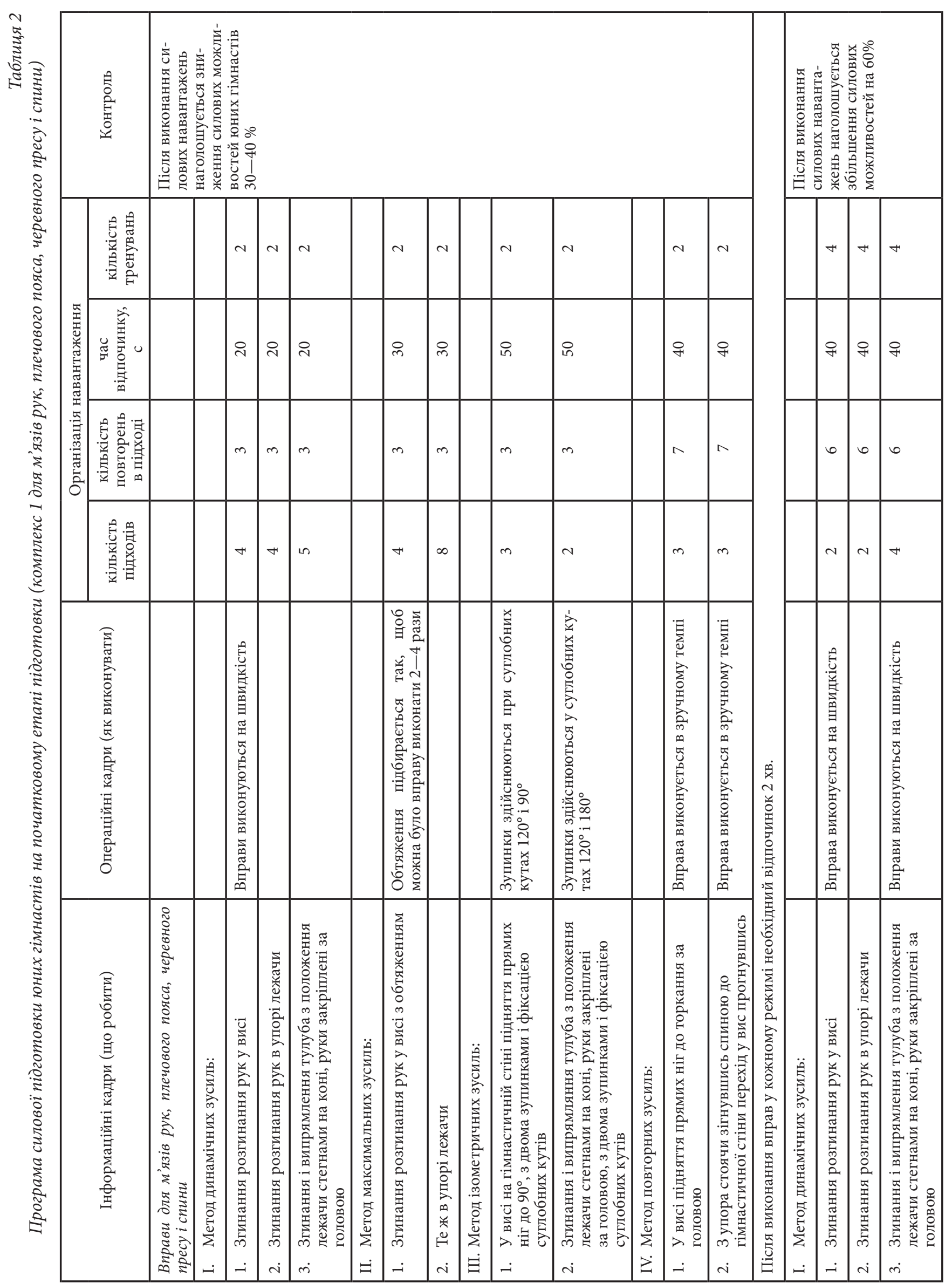




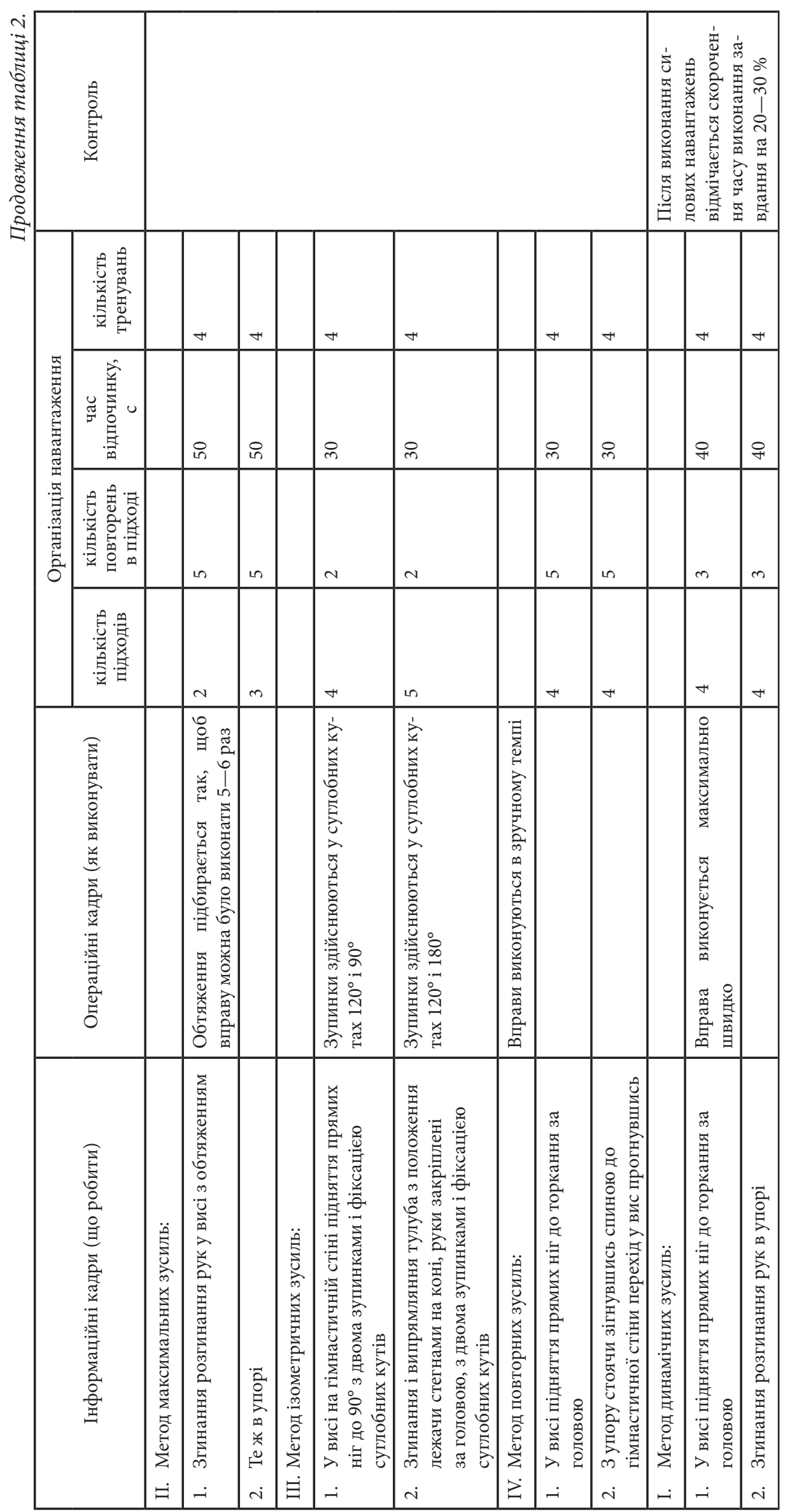




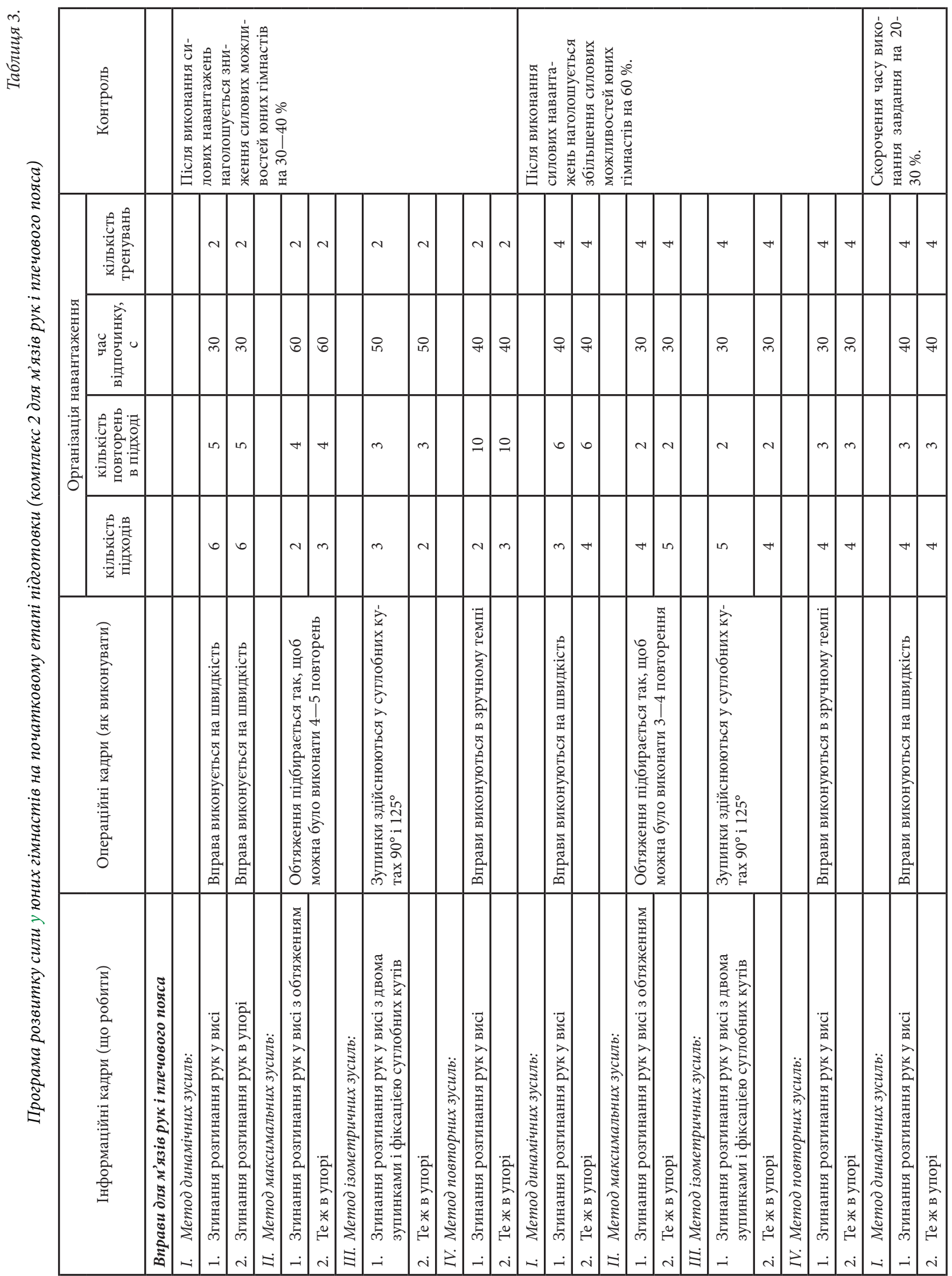




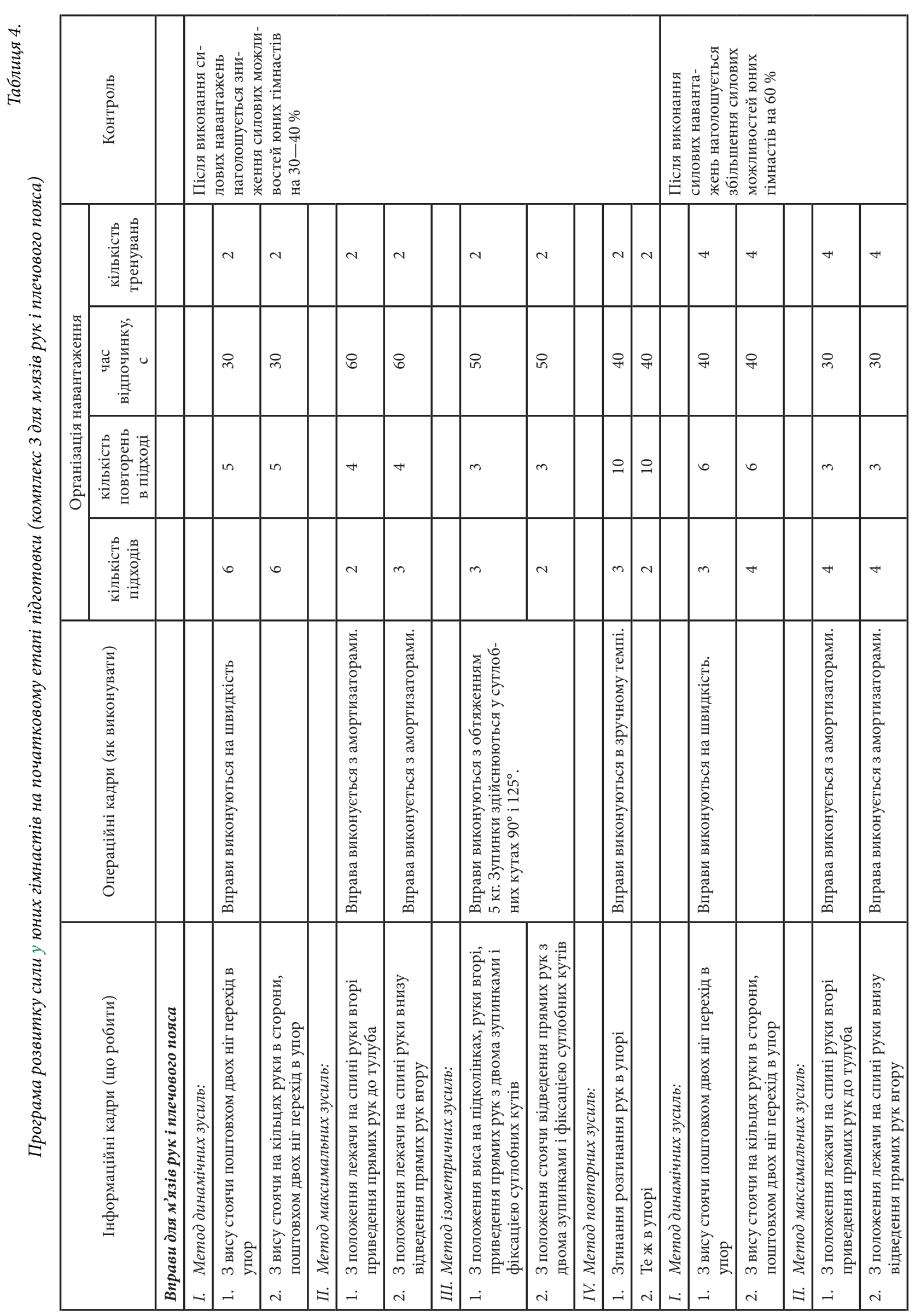




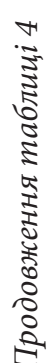
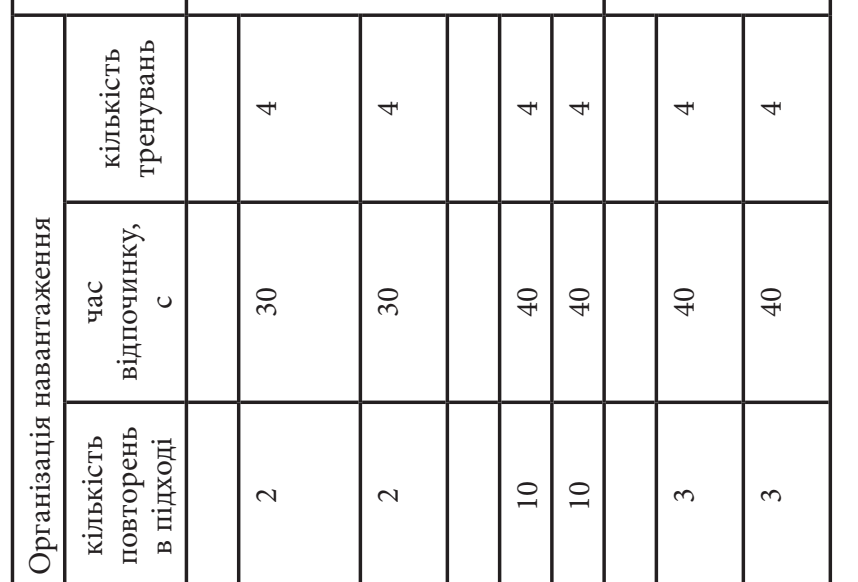

0

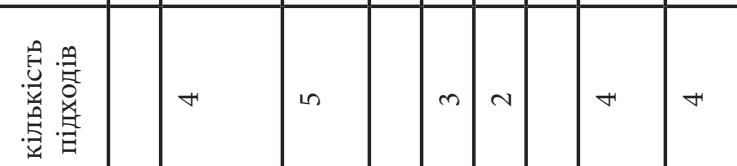

\begin{tabular}{|c|c|c|c|c|c|c|c|c|c|}
\hline 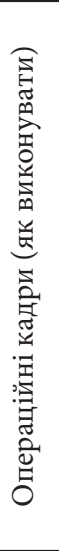 & & 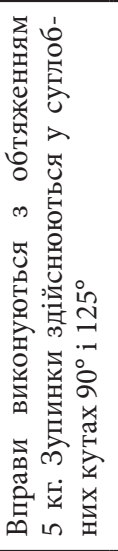 & & & 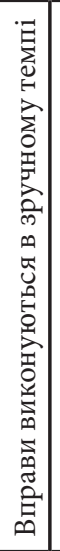 & & & 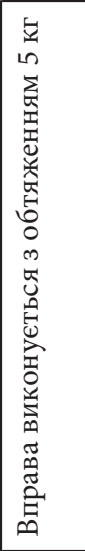 & 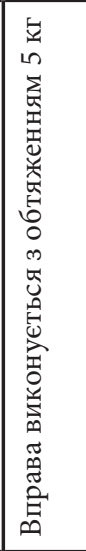 \\
\hline 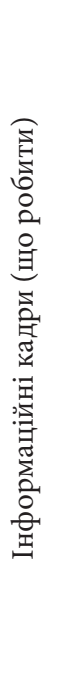 & 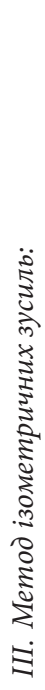 & 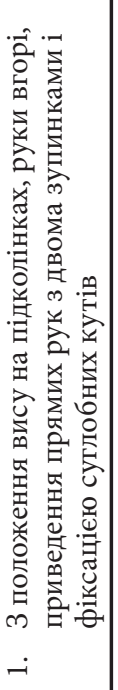 & 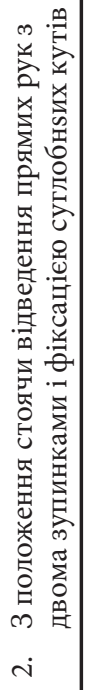 & 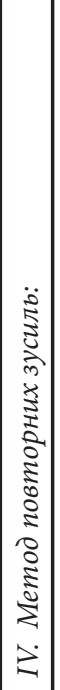 & 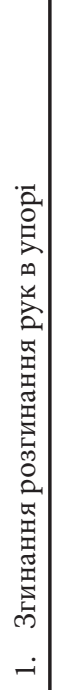 & 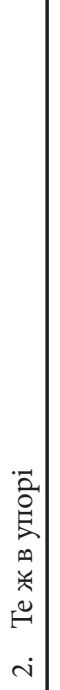 & 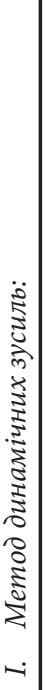 & 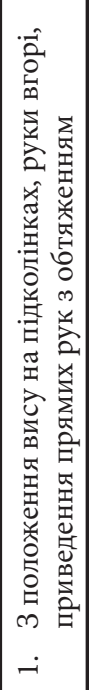 & 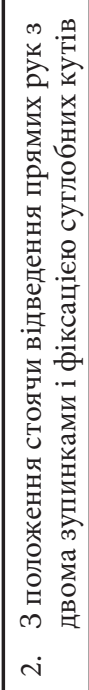 \\
\hline
\end{tabular}

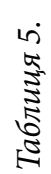

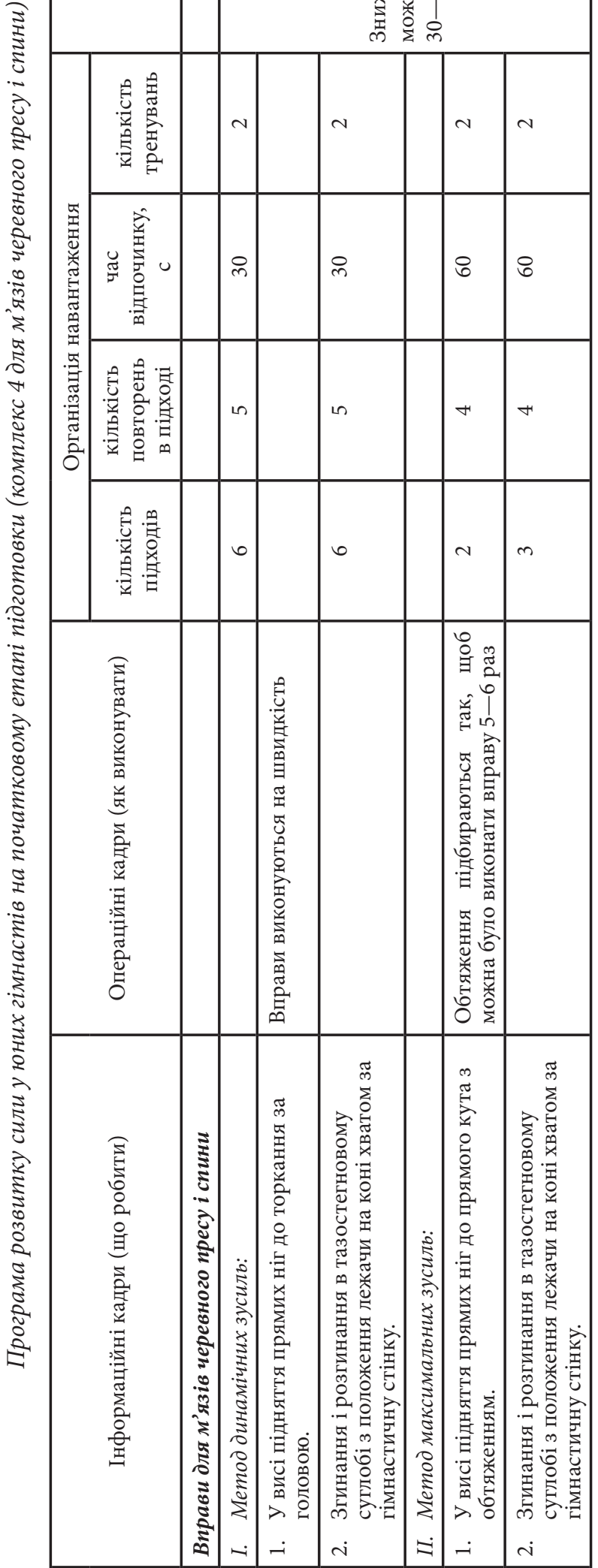




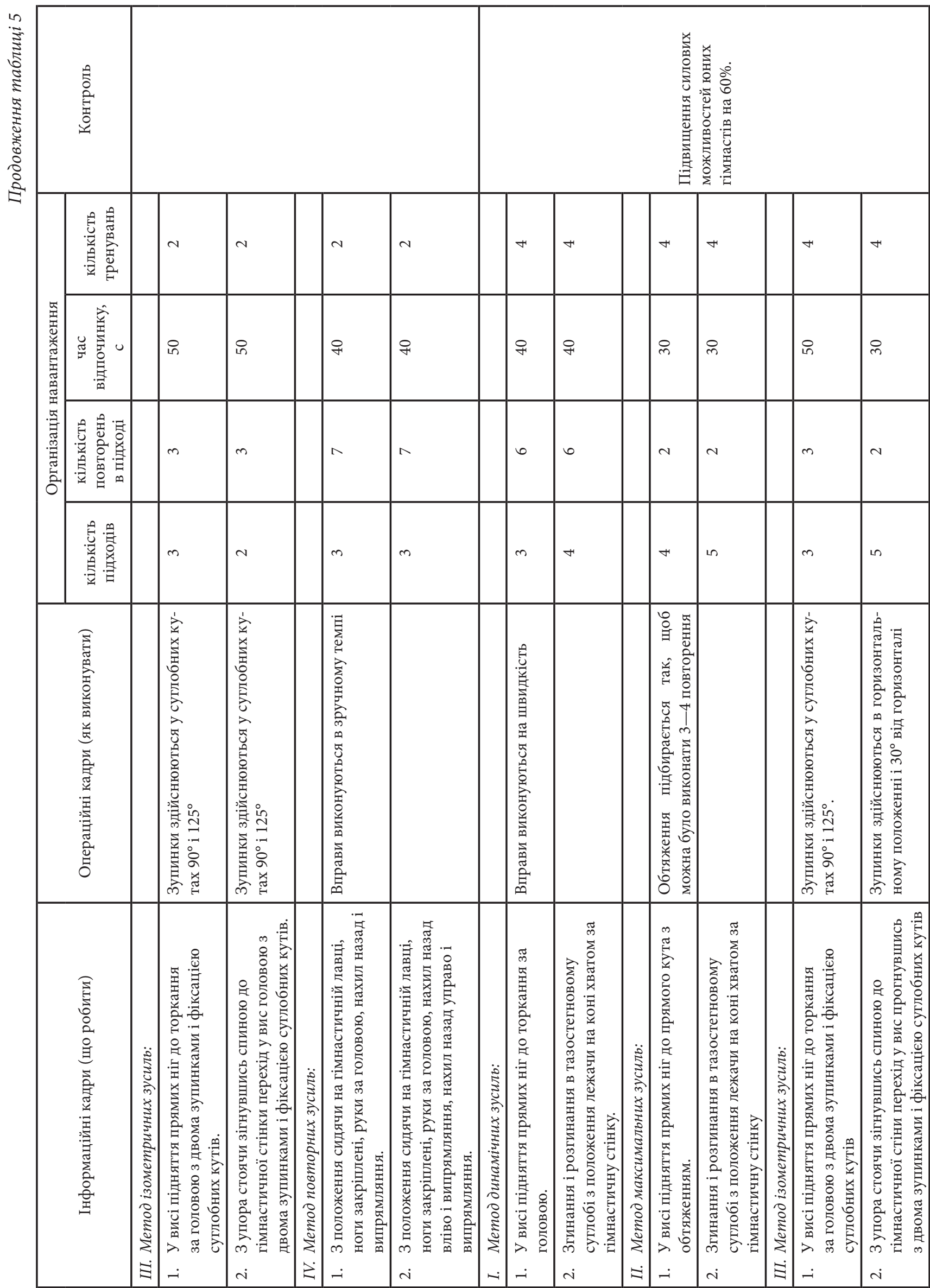



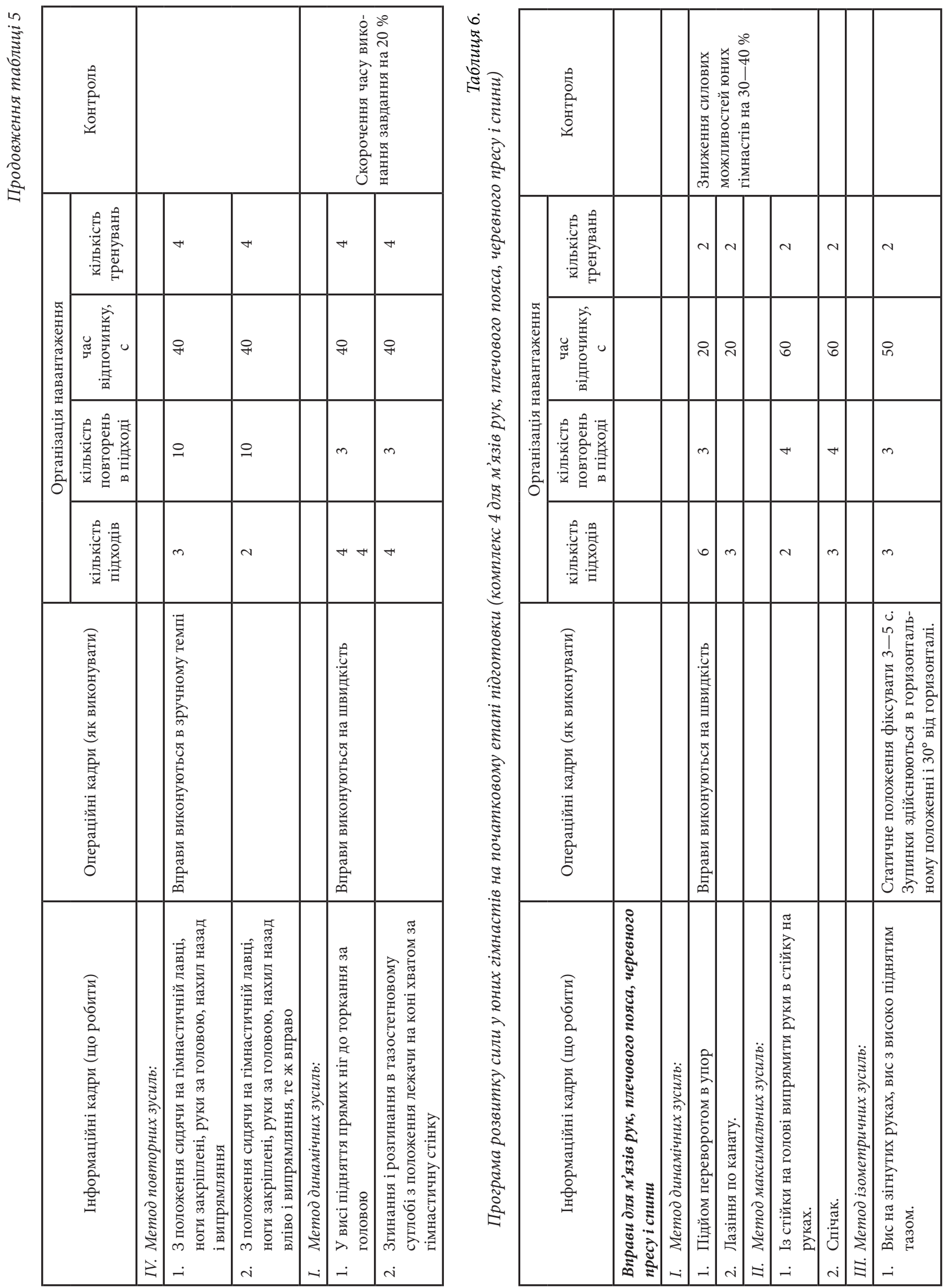


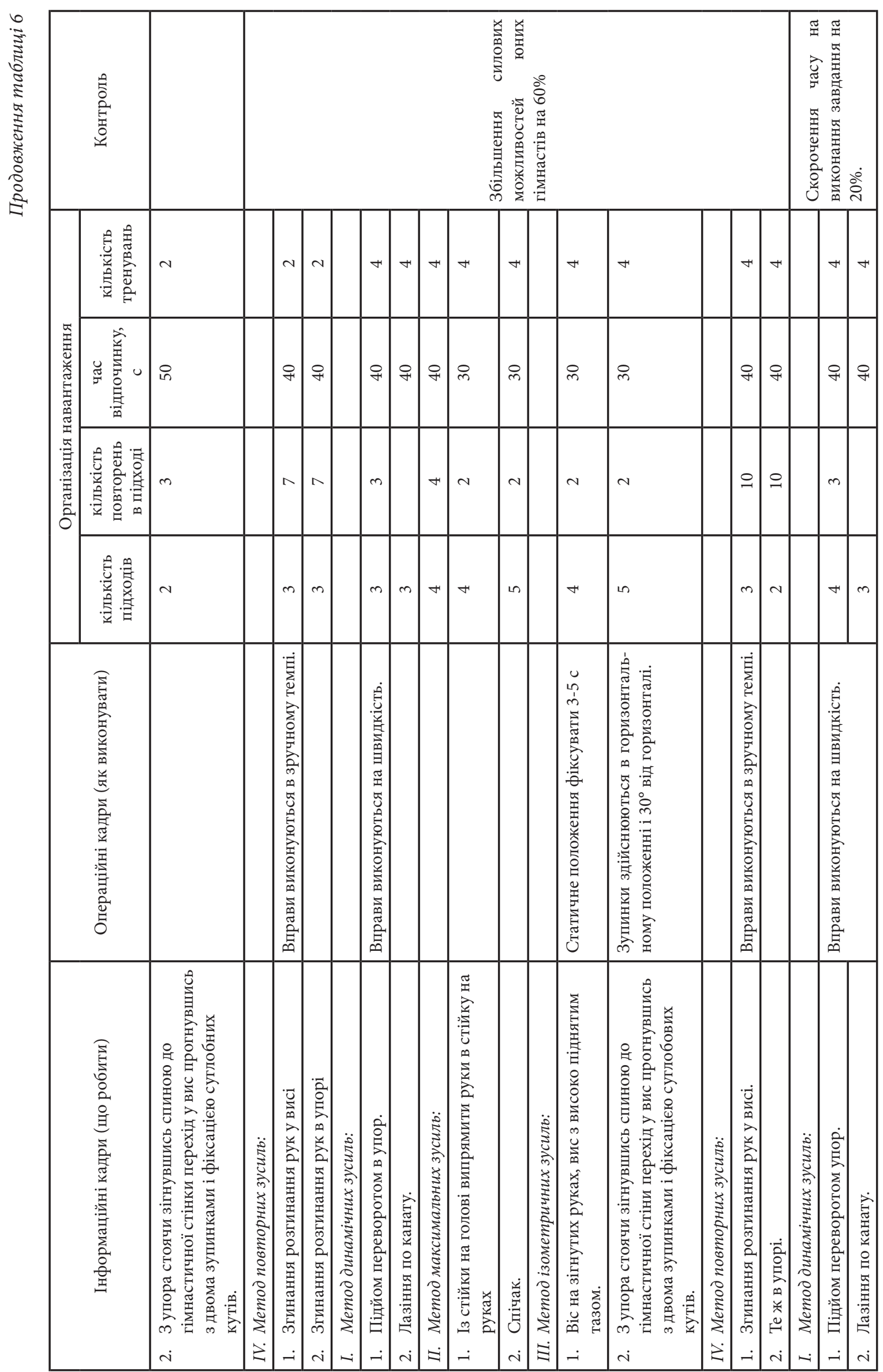




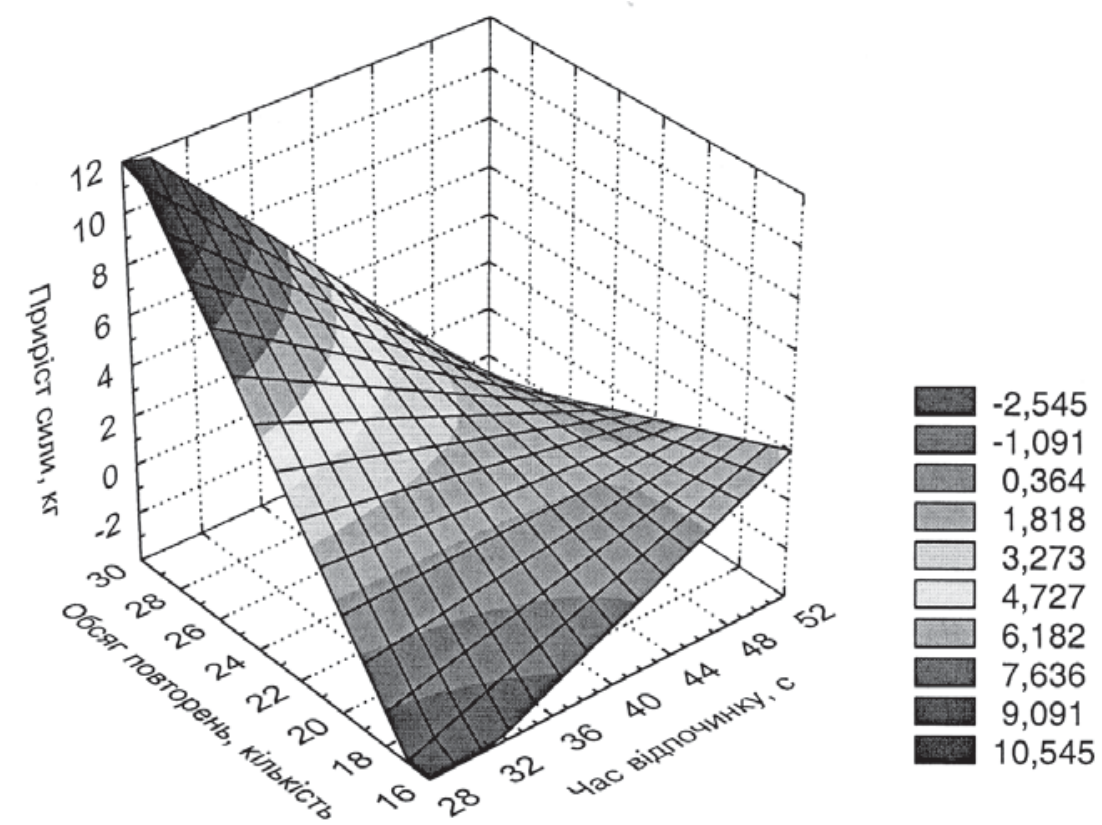

Рис. 2. Трьохвимірний розподіл приростів сили розгиначів передпліччя у юних гімнастів за результатами обчислювального експерименту

1) виконується силова робота в різних режимax;

2) силова робота поєднується з об’ємною роботою в одному занятті.

У результаті дослідження встановлено:

1) ефективним для розвитку максимальної сили є комбінований метод;

2) швидкісно-силова робота повинна проводитися безпосередньо після підвищення максимальної сили.

Відповідно до вищевикладеного в таблицях 2-6 наведені програми розвитку сили у юних гімнастів на початковому етапі підготовки. У кожному місячному циклі силової підготовки після виконання силових навантажень з періодом відновлення більше 24 годин (2 заняття) наголошується зниження силових можливостей юних гімнастів на 30-40\%. Після виконання силових навантажень 3 періодом відновлення менше 24 годин (4 заняття) наголошується збільшення силових можливостей на 60\%. Після виконання силових навантажень швидкісно-силового характеру відмічається скорочення часу виконання завдання на 20-30\% (4 заняття).

Таким чином, технологія розвитку силових здібностей включає в себе:

- аналіз вікових, статевих та індивідуальних особливостей розвитку силових та швидкісно-силових здібностей;
- реалізацію принципів фізичного виховання в процесі розвитку сили;

- методика розвитку сили (засоби розвитку сили; методи розвитку сили; навантаження і відпочинок у процесі розвитку сили; програмування, форми організації занять у процесі розвитку сили);

- педагогічний контроль за розвитком силових здібностей.

\section{Список літератури}

1. Верхошанский Ю.В. Программирование и организация тренировочного процесса / Верхошанокий Ю.В. - М.: Физкультура и спорт, 1985. - 176 с.

2. Верхошанский Ю.В. Основы специальной физической подготовки спортсменов / Верхошанский Ю.В.. - М.: Физкультура и спорт, 1988. - С. 123-140.

3. Волков А.В. Планирование тренировочной нагрузки при развитии мышечной силы в связи с периодическими изменениями функционального состояния двигательного аппарата спортсмена (на примере гимнастов старших разрядов): Дис. ... канд.пед. наук: 13.00.04 / Волков А.В. - Киев, 1970. - 128 с.

3. Матвеев Л.П. Теория и методика физической культуры. - М.: Физкультура и спорт, 1991. - С. 181-211. 
4. Меерсон Ф.З., Пиенникова М.Г. Адаптация к стрессорным ситуациям и физическим нагрузкам. - М.: «Медииина», 1988. - 252 c.

5. Менхин Ю.В. Физическая подготовка в гимнастике / Менхин Ю.В. - М.: Физкультура и спорт, 1989. - 224 с.

6. Москаленко Н.В. Фізичне виховання молодших школярів: [монографія]. - Д.: Інновація, 2007. - 252 с.

7. Платонов В.М., Булатова М.М. Фізична підготовка спортсмена. - К.: Олімпійська література, 1995. C. $109-216$.

8. Романенко В.А. Двигательные способности человека. - Донецк.: Изд-во ДонНУ, 2005. - С. 125-138.

9. Теория и методика физического воспитания. Общие основы теории и методики физического воспитания: Учебник в 2-х томах / Под редакцией Т.Ю. Круцевич. - Том 1. - К.: Олимпийская литература, 2003. C. $192-221$.
10. Теория и методика физического воспитания: Учеб. для студентов фак.физ.культуры / Под ред. Б.А. Ашмарина. - М.: Просвещение, 1990. - С. 136-142.

11. Худолій О.М. Основи методики викладання гімнастики: Навч. посібник. - Харків: ОВС, 2004. C. 245-259.

12. Худолей О.Н. Моделирование процесса подготовки юных гимнастов: Монография. - Харьков: ОВС, 2005. $-336 \mathrm{c}$.

13. Шиян Б.М. Теорія і методика фізичного виховання школярів. Частина 1. - Тернопіль: Навчальна книга - Богдан, 2001. - С. 177-196.

Надійшла до редакиії 12.12.2010 p.

Худолей О.Н. Закономерности развития силовых способностей в физическом воспитание и спорте. Доклад 2. В статье обобщенны подходы к развитию силовых способностей. Рассмотренны понятия о силовых способностях; возрастные, половые и индивидуальные особенности развития силовых и скоростно-силовых способностей; реализация принципов физического воспитания в процессе развития силы; методика развития силы (средства развития силы; методы развития силы; нагрузка и отдых в процессе развития силы; формы организации занятий в процессе развития силы); педагогический контроль за развитием силовых способностей. Ключевые слова: силовые способности, средства развития силы, методы развития силы, нагрузка и отдых.

Khudolii O.N. Conformity to the law of development of power capabilities in physical education and sport. Lecture 2. In article obobshenni approaches to development of power capabilities. Rassmotrenni notions about the power capabilities; age and individual features of development of power and speed-power capabilities; realization of principles of physical education in the process of development of force; method of development of force (tools of development of force; methods of development of force; loading and rest in the process of development of force; forms of organization of getting busy in the process of development of force); pedagogical control after development of power capabilities.

Keywords: power capabilities, tools of development of force, methods of development of force, loading and rest. 